\title{
Wiring Sympathetic Neuron Subpopulations into Target-Selective Circuits for Homeostasis
}

\author{
Uwe Ernsberger
}

Institute for Clinical Neuroanatomy, Johann-Wolfgang-Goethe University, Frankfurt/Main, Germany

\section{Article Info}

\section{Article Notes}

Received: June 24, 2019

Accepted: July 30, 2019

\section{${ }^{*}$ Correspondence:}

Dr. Uwe Ernsberger, Neuroscience Center, Institute for Clinical Neuroanatomy, Johann-Wolfgang-Goethe University, 60528 Frankfurt/Main, Germany; Email: ernsberger@outlook.de.

C 2019 Brown J. This article is distributed under the terms of the Creative Commons Attribution 4.0 International License

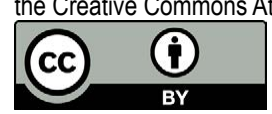

\section{Keywords:}

Noradrenergic

Cholinergic

Ntrk

Grr alpha

Ret

Target Innervation

Synapse Organizer
Abstract

The molecular characterization of postganglionic sympathetic neurons by RNA sequencing has allowed the full assessment of gene expression in individual cells and classification of neurons into subpopulations defined by their gene expression profile and developmental history. The identification of growth factor receptor subunits specifically expressed by select neuron subpopulations enabled the demonstration of GDNF family ligands and the respective receptor subunits as instrumental in the innervation of certain targets. These are first critical steps in the attempt to characterize the molecular processes leading to the establishment and maintenance of target-specific sympathetic efferent pathways.

\section{Introduction}

The knowledge on the cellular elements of the autonomic nervous system has made enormous progress since the description of preganglionic and postganglionic elements by John Newport Langley at the turn to the 20th century ${ }^{1}$. Molecular analysis focusing on key functional properties was successively refined from physiological ${ }^{2,3}$ and histological ${ }^{4}$ detection of the transmitter in noradrenergic sympathetic neurons to the detection of immunoreactivity as well as enzyme activity for the transmitter-synthesizing enzymes in the case of both noradrenergic as well as cholinergic autonomic neurons ${ }^{5-7}$. Histochemical detection of the mRNAs coding for these enzymes as well as the vesicular neurotransmitter transporters coexpressed from synexpression gene groups enabled, with highly enhanced specificity and sensitivity, the detection and developmental surveillance of neurons with a given transmitter phenotype ${ }^{8,9}$. With the dramatic advances in RNA sequencing and bioinformatical processing, data sets for the transcriptomes of individual cells are available that have been dreamed of two decades ago ${ }^{10,11}$.

Noradrenergic and Cholinergic Sympathetic Neuron Classes in the Era of Single Cell RNA Sequencing

With the advent of high throughput sequencing technologies and the massif reduction in the amount of starting RNA required for analysis, the generation of single cell transcriptomes displaced microarrays for gene expression profiling ${ }^{12,13}$. Data acquisition and analysis set complex demands on quality control and data normalization, read mapping, dimensionality reduction, feature selection and cluster analysis $^{14}$. The method then allows classification of neural subtypes and characterization of marker genes in addition to the quantitative interrogation of many features of the gene expression profile. For postganglionic sympathetic neurons, this approach has enabled the 
characterization of several noradrenergic and cholinergic subpopulations together with the partial assignment to anatomically, histologically and developmentally defined neuronal features ${ }^{10}$. In addition, analysis of the same data set allowed the characterization of noradrenergic and pan-neuronal synexpression groups of genes ${ }^{15}$. Yet the full correlation with the multitude of anatomically and physiologically defined sympathetic pathways is still open $^{16}$.

With the availability of transcriptomes for sufficiently large numbers of neurons derived from mouse stellate and thoracic sympathetic ganglia, a classification into different classes of noradrenergic (NA 1-5) and cholinergic (ACH 1 and 2) sympathetic neurons was resolved ${ }^{10}$. Interestingly, the transmitter phenotype of the ACH 1 and 2 populations is in the meantime categorized as cholinergic and

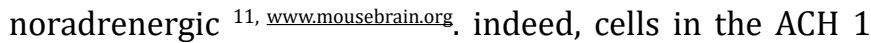
and 2 populations may not only express the cholinergic marker gene vesicular acetylcholine transporter (VAChT, Slc18a3) but also the noradrenergic marker vesicular monoamine transporter 2 (VMAT2, Slc18a2) in addition to the transmitter synthesizing enzymes ${ }^{10,15}$. This speaks to the question raised already 40 years ago whether sympathetic neurons can release acetylcholine in addition to noradrenaline ${ }^{17}$. The very large majority of the characterized neurons, however, in particular nearly all neurons classified as noradrenergic (NA) are devoid of cholinergic markers such as the vesicular acetylcholine transporter.

Some neurons first classified as cholinergic (ACH 1 and 2) as a result of the general gene expression profile lack expression of detectable transcripts for the cholinergic marker genes choline acetyltransferase (ChAT) and VAChT altogether ${ }^{10}$. The significance of this peculiar observation is currently not fully understood and entails the question for the detection limit of the RNA sequencing procedures. An explanation may be the low levels for the transcripts from the cholinergic locus genes, ranging roughly tenfold below those for the genes coding for the enzymes of the noradrenaline biosynthesis pathway ${ }^{10,15}$. In addition, their transport and distribution within the cell compartments may be responsible for the lack of reliable detection in RNA extraction procedures from the isolated soma. Another explanation may be the plasticity of transmitter phenotype in a subpopulation of sympathetic neurons ${ }^{18,19}$. These cells are distinguished by expression of cholinergic as well as noradrenergic marker genes with transcript levels depending on neuronal activity or environmental growth factor supply. However, it needs to be emphasized that the postganglionic sympathetic neurons innervating rodent sweat glands are functionally cholinergic by several physiological criteria ${ }^{6}$.

Taken together, single cell RNA sequencing has strongly promoted the characterization and classification of sympathetic neurons. For the further analysis of cell types in the autonomic nervous system, it provides a platform for the comparison of sympathetic neurons in the different paravertebral and prevertebral ganglia and for the comparison with parasympathetic neurons.

In addition to the transmitter phenotype-related and neuropeptide markers, electrophysiological and morphological features are key determinants of sympathetic neuron diversity ${ }^{20}$. The degree to which this diversity as described in mice ${ }^{21,22}$ can be correlated and approximated by RNA sequencing approaches is still open. For the appreciation of the physiological role of neurons in sympathetic efferent channels it poses an important consideration.

\section{Assigning Postganglionic Neurons to Target-Specific Sympathetic Pathways}

With increasing understanding of gene expression patterns and biochemical properties of individual autonomic neurons, the question gains momentum, how these neurons are recruited to distinct sympathetic outflow channels conveying appropriate regulation to diverse target tissues. With the analysis of reflex activation patterns in sympathetic neurons innervating different target structures, it became apparent that the SNS possesses diverse functional pathways distinguished at molecular, cellular and integrative levels ${ }^{23,24}$. Specific central autonomic networks allow for selective control of the sympathetic outflow to individual tissues and thus for the realization of patterned autonomic responses ${ }^{25,26}$. The questions whether these precisely organized pathways in the neuraxis ${ }^{27-29}$ possess specific molecular signatures and how these arise during development are now becoming addressed.

Apart from noradrenergic and cholinergic neurotransmitter phenotype-related markers and neuropeptides, neurotrophin receptor (Ntrk) and GDNF family ligand receptor (Gfr alpha and Ret) subunits appear as preferentially expressed in selected sympathetic neuron subpopulations ${ }^{10}$. The noradrenergic NTRK1/TRKAexpressing neuronal subpopulations NA2, NA4 and NA5 reexpress Ret during postnatal development concomitant with target innervation. By analyzing expression with immunohistochemistry for the receptor subunit proteins and neuropeptide NPY in sympathetic fiber tracts adjacent to the target structures in combination with retrograde labeling from target areas, selected neuron subpopulations were further characterized. NA2 neurons represent the Gfra3- and NPY-positive sympathetic subpopulation innervating nipple erector muscle. NA5 neurons constitute the Gfra2-positive but NPY-negative subpopulation innervating piloerector muscle. Importantly, with a combination of conditional gene inactivation at advanced 
developmental stages and immunohistochemical detection of sympathetic fibers in the mutant target tissues, it was demonstrated that, via developmentally regulated expression of the Gfra 2 and 3 ligands artemin and neurturin in combination with postnatal induction of Ret expression in a subpopulation of sympathetic neurons, the innervation of the respective target tissues is regulated ${ }^{10}$.

The study demonstrates how the knowledge on subpopulation-specific gene expression provides tools not only to identify the diverse neuronal populations but also to characterize the mechanisms of integration of these populations into autonomic neuron circuits. These data extend earlier knowledge on the role of neurotrophin ${ }^{30-32}$ and GDNF family ligand ${ }^{10,33,34}$ signaling in sympathetic neuron target innervation. Additional growth factor families are involved in this process such as endothelins and semaphorins ${ }^{35,36}$ or the vascular endothelial growth factor and Eph/ephrin family members ${ }^{37,38}$. The full complement of signaling decisions on the route from the developing sympathetic ganglion through the appropriate nerve branches to the proper target still have to be worked out.

Uncovering Aspects of the Neurochemical Code of Sympathetic Pathways by Immunohistochemistry and Retrograde Labeling

Neurochemical and retrograde labeling approaches have provided early insight into the molecular code of selected sympathetic target-directed pathways. Immunohistochemistry for neuropeptide Y (NPY), expressed in noradrenergic cardiovascular sympathetic neurons ${ }^{39,40}$ as well as vasoactive intestinal peptide (VIP) and calcitonin gene-related peptide (CGRP) expressed in cholinergic sudomotor neurons ${ }^{41}$ has been used for the characterization of the respective preganglionic neurons.

Applying immunohistochemistry for corticotrophin releasing factor-like immunoreactivity (CRF-LI) in cat stellate and lumbar sympathetic ganglia resulted in the staining of terminal baskets derived from innervating preganglionic neurons surrounding 96 to $99 \%$ TH-negative, but CGRP-positive postganglionic neuronal cell bodies ${ }^{42}$. Conversely, retrograde labeling from the paw innervated by sudomotor and vasoconstrictor neurons with fluorogold labeled postganglionic sympathetic ganglion cells including approximately $30 \%$ somata surrounded by CRF-LI terminal baskets.

Retrograde labeling with different dyes applied to the heart ventricle or the cut end of the cardiac nerve in the rat disclosed NPY-positive and negative postganglionic sympathetic neuron populations ${ }^{43}$. Association of NPYpositive cell bodies in rodent stellate and superior cervical ganglia with synaptic baskets positive for cocaine and amphetamine-regulated transcript peptide (CART) allowed the characterization of innervating preganglionic neurons in the cardiovascular pathways as CART-positive cells ${ }^{44}$. The finding was confirmed by transneuronal tracing using pseudorabies virus from skeletal muscle demonstrating the innervation of NPY-positive vasoconstrictor neurons by CART-positive preganglionic neurons.

By combination of immunohistochemistry for neuropeptides and calcium binding proteins with retrograde labeling and nerve transection, initial characterization of sympathetic pathways to additional targets such as the iris and submandibular glands were performed $^{45,46}$.

Thus, the combination of peptideimmunohistochemistry and retrograde labeling was able to characterize several features of sympathetic pathways innervating the heart and the vasculature as well as sweat glands in two classical model systems, the cat and the rat. Transneuronal tracing with neurotropic virus expressing fluorescent marker proteins promises to allow selection of neurons in given sympathetic pathways for RNA sequencing. In this manner, the full transcriptome in these pathways may become unveiled and provide information on their equipment with gene products involved in contact formation and information propagation between neurons and targets.

The establishment of Specific Synaptic Connections from Preganglionic to Postganglionic Neurons

The formation of the proper synaptic connections between the pre- and postganglionic sympathetic neurons is key to the establishment of the diverse functional pathways supplying appropriately patterned sympathetic activity to the target organs ${ }^{23,25}$.

Distinct regulation is demonstrated for sympathetic outflow channels subserving different functional contexts. This can be observed for sympathetic innervation to vasoregulatory and thermoregulatory effectors ${ }^{47,48}$. It is detected for the innervation of a range of target organs such as the heart as compared to kidney ${ }^{49,50}$ or to spleen ${ }^{51-53}$. Also, differential regulation of the blood circulation in distinct somatic and intestinal vascular beds is accomplished by distinct patterns of efferent sympathetic activity ${ }^{54,55}$. Skin and muscle blood flow are distinctly regulated ${ }^{56-59}$.

The molecular logic that enables the development and sustains the maintenance of this diversity in sympathetic efferent pathways is currently not fully understood. During development it is a multistep process including among others synapse formation of preganglionic onto postganglionic sympathetic neurons and formation of appropriate synaptic contacts between central pre-motor neurons and the appropriate preganglionic neurons.

A critical set of events in this multistep process is the final choice of the appropriate postganglionic targets by 
preganglionic neurons, the initial synapse formation and the regulation of synapse number during maturation. In different populations of autonomic neurons the postnatal refinement of synapse numbers has been documented by electrophysiological recording ${ }^{60}$. Neurotrophin signaling depending on growth factors derived from the target ${ }^{61,31}$ as well as from the preganglionic neurons ${ }^{62,63}$, and their activity dependence has been characterized. However, the processes responsible for establishment of specificity in development of the diverse target-specific sympathetic pathways are unknown.

\section{Lessons from Spinal Motor Neuron Specification}

For spinal motor neurons, developmental specification and integration into circuits required for coordinated muscle movement has been analyzed using genetic approaches in mice ${ }^{64,65}$. Several features important for specific innervation of skeletal muscle targets by spinal motoneurons are also relevant for the development of target-specific sympathetic pathways: migration and coalescence of the differentiating motoneurons to their final dorsoventral positions in spinal cord columns ${ }^{66,67}$, the innervation of the appropriate $\operatorname{target}^{68}$, and targetdependent maturation processes that affect connectivity within the spinal cord ${ }^{69}$.

The processes entail transcriptional specification involving Hox proteins and regulatory ret signaling ${ }^{70-72}$. The ret ligand GDNF and its receptor subunit GFRa1 are required for correct positioning of motor neuron cell bodies in the spinal cord, invasion of embryonic target tissue, and induction of the ETS transcription factor Pea3 in a motoneuron subpopulation ${ }^{73}$. Pea3 is prerequisite for correct positioning of the motoneurons within the spinal cord and normal axon branching within the target ${ }^{74}$. The observations demonstrate a signaling sequence from the target-derived growth factor resulting in proper maturation, positioning and target innervation of a motoneuron subpopulation. Hox proteins coordinate motoneuron subtype specification, determine ret expression levels and define GFRa subunit profiles $^{72}$.

Interestingly, the ETS transcription factor Er81, expressed in a nonoverlapping motor and a sensory neuron subpopulation, is required for establishment of the appropriate synaptic contacts between the motoneurons and their sensory input ${ }^{75}$. The neurotrophin NT3 is required for Er81 expression in the sensory neurons ${ }^{76}$. These observations illustrate the involvement of GDNF family ligand and neurotrophin signaling in the differentiation of spinal cord motor circuits. Thus, both growth factor and receptor families are involved in motoneuron and sympathetic neuron differentiation.

In a comparable manner, such an analysis is expected to not only provide understanding of the molecular mechanisms underlying target-selective outgrowth of sympathetic nerve fibers. In addition, it may shed light on the positioning of preganglionic cell bodies in targetspecific cell clusters in the intermediolateral cell column of the spinal cord ${ }^{77}$. Moreover, an analysis of the principles underlying the synaptic organization of distinct functional pathways in sympathetic ganglia ${ }^{78}$ appears to become experimentally accessible.

\section{Progressing from Axonal Pathfinding to Selective Synapse Formation}

A question of particular interest is the association and interaction of these signaling systems with proteins acting as guidance cues and in particular membrane-associated proteins suitable to mediate cell-adhesion and cell-type identification ${ }^{79,80}$. In the case of spinal motoneurons this has been shown for ret and Eph/ephrin signaling ${ }^{81}$ by cooperative interaction of the two signaling systems ${ }^{82}$. Also, protocadherins expressed in motoneurons ${ }^{83}$ are engaged with ret in mutual regulation and stabilization as shown in stem cell derived motoneurons and primary postganglionic sympathetic neurons ${ }^{84}$.

in addition, synaptic organizer hubs of the neurexin and neuroligin ${ }^{85,86}$ as well as the receptor - protein tyrosine phosphatase (LAR-RPTP) ${ }^{87,88}$ families will attract interest. In postganglionic sympathetic neurons neurexin induction and splice variant expression is regulated during maturation and target innervation ${ }^{89}$. However, developmental regulation of their binding partners, in particular neuroligins, and the expression of both protein families in preganglionic sympathetic neurons is not analyzed. The study of the role of the above-mentioned signaling systems in interaction with these synaptic organizers in the establishment of target-specific sympathetic pathways can be expected to be of outstanding relevance.

\section{Conclusions}

The molecular characterization of the cellular elements in the sympathetic nervous system was greatly refined during the last three decades. From the demonstration of functional signature genes such as tyrosine hydroxylase and choline acetyltransferase it progressed to the characterization of the full transcriptome detected in cell bodies of postganglionic neurons in selected mouse sympathetic ganglia. With functional characterization of an ever-increasing selection of gene products, the interrogation of neuronal circuits moves to a new level. On the one hand, the characterization of transcriptomes of large numbers of individual neurons allows the classification of sympathetic neuron subpopulations and, to a certain extent, their functional characterization. On the other hand, the knowledge on the subpopulation-specific expression of a range of marker genes opens, comparable to the study of the spinal motoneuron circuits, the analysis 
of target-specific sympathetic pathways. This involves not only the study of the projection of preganglionic neurons to their postganglionic partners and to the final targets but also the analysis of the innervation from the distinct autonomic CNS centers by premotor to preganglionic neurons. This compilation of data promises to unravel the sympathetic autonomic neural circuits required for the synchronization of circulation and temperature regulation, balancing of the fluid matrix, regulation of bowel function and sexual organs among others.

\section{Acknowledgments}

The continuous discussion on the topic with Hermann Rohrer and the introduction to the diverse sympathetic pathways by Wilfried Jaenig are gratefully acknowledged. I am indebted to Thomas Deller for the possibility of guest scientist affiliation with his Institute. I thank three unknown reviewers for their critical and careful analysis of the manuscript. Ute Wagner and Pedro Zieba made things possible.

\section{References}

1. Langley JN, The autonomic nervous system (Pt 1), 1921). W.Heffer \& Sons Ltd., Cambridge.

2. von Euler US. Sympathin E and Nor-Adrenaline. Science. 1948;107(2782):422.

3. von Euler US. Twenty years of noradrenaline. Pharmacol Rev 1966;18(1):29-38.

4. Falck B, Hillarp NA, Thieme G, Torp A. Fluorescence of catecholamines and related compounds condensed with formaldehyde. J. Histochem Cytocherm. 1962;10, 348-354.

5. Black IB, Patterson PH. Developmental regulation of neurotransmitter phenotype. Curr Top Dev Biol. 1980;15 Pt 1:27-40

6. Landis SC. Target regulation of neurotransmitter phenotype. Trends Neurosci. 1990 Aug;13(8):344-50. Review.

7. Francis NJ, Landis SC. Cellular and molecular determinants of sympathetic neuron development. Annu Rev Neurosci. 1999;22:54166. Review.

8. Ernsberger U, Rohrer H. Development of the cholinergic neurotransmitter phenotype in postganglionic sympathetic neurons. Cell Tissue Res. 1999 Sep;297(3):339-61.

9. Ernsberger U. Evidence for an evolutionary conserved role of bone morphogenetic protein growth factors and phox2 transcription factors during noradrenergic differentiation of sympathetic neurons. Induction of a putative synexpression group of neurotransmittersynthesizing enzymes. Eur J Biochem. 2000 Dec;267(24):6976-81.

10. Furlan A, La Manno G, Lübke $M$, Häring $M$, Abdo $H$, Hochgerner $H$, Kupari J, Usoskin D, Airaksinen MS, Oliver G, Linnarsson S, Ernfors P. Visceral motor neuron diversity delineates a cellular basis for nipple- and pilo-erection muscle control. Nat Neurosci. 2016 Oct;19(10):1331-40. doi: 10.1038/nn.4376. Epub 2016 Aug 29.

11. Zeisel A, Hochgerner $H$, Lönnerberg $P$, Johnsson A, Memic F, van der Zwan J, Häring M, Braun E, Borm LE, La Manno G, Codeluppi $S$, Furlan A, Lee K, Skene N, Harris KD, Hjerling-Leffler J, Arenas E, Ernfors P, Marklund U, Linnarsson S. Molecular Architecture of the Mouse Nervous System. Cell. 2018 Aug 9;174(4):999-1014.e22. doi: 10.1016/j.cell.2018.06.021

12. McGettigan PA. Transcriptomics in the RNA-seq era. Curr Opin Chem
Biol. 2013 Feb;17(1):4-11. doi: 10.1016/j.cbpa.2012.12.008. Epub 2013 Jan 2.

13. Sandberg R. Entering the era of single-cell transcriptomics in biology and medicine. Nat Methods. 2014 Jan;11(1):22-4.

14. Chen G, Ning B, Shi T. Single-Cell RNA-Seq Technologies and Related Computational Data Analysis. Front. Genet. 2019;10:317. doi: 10.3389/fgene.2019.00317

15. Ernsberger U, Kramer M, Tsarovina K, Deller T, Rohrer H. Coordinate expression of pan-neuronal and functional signature genes in sympathetic neurons. Cell Tissue Res. 2017 Nov;370(2):227-241. doi: 10.1007/s00441-017-2688-7. Epub 2017 Sep 21. Erratum in: Cell Tissue Res. 2017 Nov 10;:.

16. Ernsberger U, Rohrer H. Sympathetic tales: subdivisons of the autonomic nervous system and the impact of developmental studies. Neural Dev. 2018; 13(1):20.

17. Burnstock G. Do some sympathetic neurones synthesize and release both noradrenaline and acetylcholine? Prog Neurobiol. 1978;11(34):205-22.

18. Yang B, Slonimsky JD, Birren SJ. A rapid switch in sympathetic neurotransmitter release properties mediated by the p75 receptor Nat Neurosci. 2002 Jun;5(6):539-45.

19. Luther JA, Enes J, Birren SJ. Neurotrophins regulate cholinergic synaptic transmission in cultured rat sympathetic neurons through a p75-dependent mechanism. J Neurophysiol. 2013 Jan;109(2):485-96. doi: 10.1152/jn.00076.2011. Epub 2012 Oct 31.

20. Gibbins I. Functional organization of autonomic neural pathways. Organogenesis 2013;9:3, 169-175

21. Jobling P, Gibbins IL. Electrophysiological and morphological diversity of mouse sympathetic neurons. J. Neurophysiol. 1999;82: 2747-2764.

22. Anderson RL,Jobling P, Gibbins IL. Development of Electrophysiological and Morphological Diversity in Autonomic Neurons. J Neurophysiol. 2001;86: 1237-1251.

23. Jänig W, McLachlan EM. Characteristics of function-specific pathways in the sympathetic nervous system. Trends Neurosci. 1992 Dec;15(12):475-81.

24. Jänig W, The integrative action of the autonomic nervous system: neurobiology of homeostasis (2006). Cambridge: Cambridge University Press;

25. Morrison, SF. Differential control of sympathetic outflow. Am J Physiol Regulatory Integrative Comp Physiol 2001;281: R683-R698,

26. Barman SM, Yates BJ. Deciphering the Neural Control of Sympathetic Nerve Activity: Status Report and Directions for Future Research. Front. Neurosci. 2017:11:730.

27. Jänig W, Häbler HJ. Specificity in the organization of the autonomic nervous system: a basis for precise neural regulation of homeostatic and protective body functions. Prog Brain Res. 2000;122:351-67.

28. Iriki M, Simon E. Differential control of efferent sympathetic activity revisited. J Physiol Sci. 2012 Jul;62(4):275-98. doi: 10.1007/s12576012-0208-9. Epub 2012 May 22.

29. Sved AF, Cano G, Card JP. Neuroanatomical specificity of the circuits controlling sympathetic outflow to different targets. Clin Exp Pharmacol Physiol. 2001 Jan-Feb;28(1-2):115-9.

30. Glebova NO, Ginty DD. Heterogeneous requirement of NGF for sympathetic target innervation in Vivo. J. Neurosci. 2004;24(3):743751

31. Lehigh KM, West KM, Ginty DD. Retrogradely Transported TrkA Endosomes Signal Locally within Dendrites to Maintain Sympathetic Neuron Synapses. Cell Rep. 2017 Apr 4;19(1):86-100. doi: 10.1016/j. celrep.2017.03.028. 
32. Ernsberger U. Role of neurotrophin signalling in the differentiation of neurons from dorsal root ganglia and sympathetic ganglia. Cell Tissue Res. 2009 Jun;336(3):349-84. doi: 10.1007/s00441-009-0784-z Epub 2009 Apr 23.

33. Enomoto H, Crawford PA, Gorodinsky A, Heuckeroth RO, Johnson EMJr, Milbrandt J. RET signaling is essential for migration,axonal growth and axon guidance of developing sympatheticneurons. Development 2001;128:3963-3974

34. Ernsberger U. The role of GDNF family ligand signalling in the differentiation of sympathetic and dorsal root ganglion neurons. Cell Tissue Res. 2008 Sep;333(3):353-71. doi: 10.1007/s00441-0080634-4. Epub 2008 Jul 16.

35. Makita T, Sucov HM, Gariepy CE, Yanagisawa M, Ginty DD. Endothelins are vascular-derived axonal guidance cues for developing sympathetic neurons. Nature. 2008 Apr 10;452(7188):759-63. doi: 10.1038/ nature 06859 .

36. Poltavski DM, Colombier P, Hu J, Duron A, Black BL, Makita T. Venous endothelin modulates pop responsiveness of cardiac sympathetic axons to arterial semaphorin. Elife. 2019 Feb 8;8. pii: e42528. doi 10.7554/eLife.42528.

37. MarkoSB, Damon DH.VEGF promotes vascular sympathetic innervation. Am J Physiol Heart Circ Physiol. 2008 Jun;294(6):H2646-52. doi: 10.1152/ajpheart.00291.2008. Epub 2008 Apr 11.

38. Damon DH, teRiele JA, Marko SB. Eph/ephrin interactions modulate vascular sympathetic innervation. Auton Neurosci. 2010 Dec 8;158(12):65-70. doi: 10.1016/j.autneu.2010.06.004. Epub 2010 Jul 15.

39. Anderson CR. Identification of cardiovascular pathways in the sympathetic nervous system. Clin Exp Pharmacol Physiol. 1998 Jun;25(6):449-52.

40. Hodges GJ, Jackson DN, Mattar L, Johnson JM, Shoemaker JK Neuropeptide $Y$ and neurovascular control in skeletal muscle and skin Am J Physiol Regul Integr Comp Physiol. 2009 Sep;297(3):R546-55. doi: 10.1152/ajpregu.00157.2009. Epub 2009 Jul 1.

41. Lindh B, Hökfelt T. Structural and functional aspects of acetylcholine peptide coexistence in the autonomic nervous system. Prog Brain Res. 1990;84:175-91.

42. Shafton AD, Oldfield BJ, McAllen RM. CRF-like immunoreactivity selectively labels preganglionic sudomotor neurons in cat. Brain Res. 1992 Dec 25;599(2):253-60

43. Richardson RJ, Grkovic I, Allen AM, Anderson CR. Separate neurochemical classes of sympathetic postganglionic neurons project to the left ventricle of the rat heart. Cell Tissue Res. 2006 Apr;324(1):9-16. Epub 2006 Jan 18.

44. Gonsalvez DG, Cane KN, Landman KA, Enomoto H, Young HM Anderson CR. Proliferation and cell cycle dynamics in the developing stellate ganglion. J Neurosci. 2013 Apr 3;33(14):5969-79. doi: 10.1523/JNEUROSCI.4350-12.2013.

45. Grkovic I, Anderson CR. Calretinin-containing preganglionic nerve terminals in the rat superior cervical ganglion surround neurons projecting to the submandibular salivary gland. Brain Res. $1995 \mathrm{Jul}$ 3;684(2):127-35.

46. Grkovic I, Edwards SL, Murphy SM, Anderson CR. Chemically distinct preganglionic inputs to iris-projecting postganglionic neurons in the rat: A light and electron microscopic study. J Comp Neurol. 1999 Oct 4;412(4):606-16.

47. Morrison SF. Differential regulation of sympathetic outflows to vasoconstrictor and thermoregulatory effectors. Ann N Y Acad Sci. 2001;940:286-98

48. Morrison SF, Nakamura K. Central Mechanisms for Thermoregulation. Annu Rev Physiol. 2019 Feb 10;81:285-308. doi: 10.1146/annurevphysiol-020518-114546. Epub 2018 Sep 26.
49. Kawada T, Shishido T, Inagaki M, Tatewaki T, Zheng C, Yanagiya Y, Sugimachi M, Sunagawa K. Differential dynamic baroreflex regulation of cardiac and renal sympathetic nerve activities. Am J Physiol Heart Circ Physiol. 2001 Apr;280(4):H1581-90.

50. May CN, Frithiof R, Hood SG, McAllen RM, McKinley MJ, Ramchandra R. Specific control of sympathetic nerve activity to the mammalian heart and kidney. Exp Physiol. 2010 Jan;95(1):34-40. doi: 10.1113/ expphysiol.2008.046342. Epub 2009 Jul 17.

51. Meckler RL, Weaver LC. Characteristics of ongoing and reflex discharge of single splenic and renal sympathetic postganglionic fibers in cats. J. Physiol. 1988;396:139-153

52. Jänig W. Sympathetic nervous system and inflammation: a conceptual view. Auton Neurosci. 2014 May;182:4-14. doi: 10.1016/j. autneu.2014.01.004. Epub 2014 Jan 18.

53. Bellinger DL, Lorton D. Sympathetic Nerve Hyperactivity in the Spleen: Causal for Nonpathogenic-Driven Chronic Immune-Mediated Inflammatory Diseases (IMIDs)? Int J Mol Sci. 2018 Apr 13;19(4). pii: E1188. doi: 10.3390/ijms19041188. Review.

54. Kullmann R, Schönung W, Simon E. Antagonistic changes of blood flow and sympathetic activity in different vascular beds following central thermal stimulation. I. Blood flow in skin, muscle and intestine during spinal cord heating and cooling in anesthetized dogs. Pflugers Arch. 1970;319(2):146-61

55. Pan , HL, Deal DD, Xu Z, Chen SR. Differential responses of regional sympathetic activity and blood flow to visceral afferent stimulation. Am J Physiol Regulatory Integrative Comp Physiol. 2001;280: R1781R1789.

56. Jänig W, Sundlöf G, Wallin BG. Discharge patterns of sympathetic neurons supplying skeletal muscle and skin in man and cat. J Auton Nerv Syst. 1983 Mar-Apr;7(3-4):239-56

57. Kümmel H. Activity in sympathetic neurons supplying skin and skeletal muscle in spinal cats. J Auton Nerv Syst. 1983 Mar-Apr;7(3-4):319-27.

58. Vissing SF. Differential activation of sympathetic discharge to skin and skeletal muscle in humans. Acta Physiol Scand Suppl. 1997;639:1-32.

59. Macefield VG, Wallin BG. Physiological and pathophysiological firing properties of single postganglionic sympathetic neurons in humans. J Neurophysiol. 2018 Mar 1;119(3):944-956. doi: 10.1152/ jn.00004.2017. Epub 2017 Nov 15.

60. Purves D, Lichtman JW. Formation and maintenance of synaptic connections in autonomic ganglia. Physiol Rev. 1978 Oct;58(4):82162.

61. Sharma N, Deppmann CD, Harrington AW, St Hillaire C, Chen ZY, Lee FS, Ginty DD. Long-distance control of synapse assembly by targetderived NGF. Neuron. 2010 Aug 12;67(3):422-34. doi: 10.1016/j. neuron.2010.07.018.

62. Causing CG, Gloster A, Aloyz R, Bamji SX, Chang E, Fawcett J, Kuchel G, Miller FD. Synaptic innervation density is regulated by neuronderived BDNF. Neuron. 1997 Feb;18(2):257-67.

63. Singh KK, Park KJ, Hong EJ, Kramer BM, Greenberg ME, Kaplan DR, Miller FD. Developmental axon pruning mediated by BDNF-p75NTRdependent axon degeneration. Nat Neurosci. 2008 Jun;11(6):649-58. doi: 10.1038/nn.2114. Epub 2008 Ap

64. Dalla Torre di Sanguinetto SA, Dasen JS, Arber S. Transcriptional mechanisms controlling motor neuron diversity and connectivity. Curr Opin Neurobiol. 2008 Feb;18(1):36-43. doi: 10.1016/j. conb.2008.04.002. Epub 2008 Jun 2.

65. D'Elia KP, Dasen JS. Development, functional organization, and evolution of vertebrate axial motor circuits. Neural Dev. 2018 Jun 1;13(1):10. doi: 10.1186/s13064-018-0108-7.

66. Price SR. Cell adhesion and migration in the organization of spinal 
motor neurons. Cell Adh Migr. 2012 Sep-Oct;6(5):385-9. doi: 10.4161/ cam.21044. Epub 2012 Aug 20.

67. Kim M, Bjorke B, Mastick GS. Motor neuron migration and positioning mechanisms: New roles for guidance cues. Semin Cell Dev Biol. 2019 Jan;85:78-83. doi: 10.1016/j.semcdb.2017.11.016. Epub 2017 Nov 14.

68. Bonanomi D, Pfaff SL. Motor axon pathfinding. Cold Spring Harb Perspect Biol. 2010 Mar;2(3):a001735. doi: 10.1101/cshperspect. a001735.

69. Arber S. Motor circuits in action: specification, connectivity, and function. Neuron. 2012 Jun 21;74(6):975-89. doi: 10.1016/j. neuron.2012.05.011.

70. Dasen JS, Liu JP, Jessell TM. Motor neuron columnar fate imposed by sequential phases of Hox-c activity. Nature. 2003 Oct 30;425(6961):926-33.

71. Dasen JS, Tice BC, Brenner-Morton S, Jessell TM. A Hox regulatory network establishes motor neuron pool identity and target-muscle connectivity. Cell. 2005 Nov 4;123(3):477-91.

72. Catela C, Shin MM, Lee DH, Liu JP, Dasen JS. Hox Proteins Coordinate Motor Neuron Differentiation and Connectivity Programs through Ret/Gfr $\alpha$ Genes. Cell Rep. 2016 Mar 1;14(8):1901-15. doi: 10.1016/j. celrep.2016.01.067. Epub 2016 Feb 18.

73. Haase G, Dessaud E, Garcès A, de Bovis B, Birling M, Filippi P, Schmalbruch $\mathrm{H}$, Arber S, deLapeyrière 0 . GDNF acts through PEA3 to regulate cell body positioning and muscle innervation of specific motor neuron pools. Neuron. 2002 Aug 29;35(5):893-905.

74. Livet J, Sigrist M, Stroebel S, De Paola V, Price SR, Henderson CE Jessell TM, Arber S. ETS gene Pea3 controls the central position and terminal arborization of specific motor neuron pools. Neuron. 2002 Aug 29;35(5):877-92.

75. Arber S, Ladle DR, Lin JH, Frank E, Jessell TM. ETS gene Er81 controls the formation of functional connections between group Ia sensory afferents and motor neurons. Cell. 2000 May 26;101(5):485-98.

76. Patel TD, Kramer I, Kucera J, Niederkofler V, Jessell TM, Arber S, Snider WD. Peripheral NT3 signaling is required for ETS protein expression and central patterning of proprioceptive sensory afferents. Neuron. 2003 May 8;38(3):403-16.

77. Appel NM, Elde RP. The intermediolateral cell column of the thoracic spinal cord is comprised of target-specific subnuclei: evidence from retrograde transport studies and immunohistochemistry. J Neurosci. 1988 May;8(5):1767-75.
78. Gibbins IL, Jobling P, Messenger JP, Teo EH, Morris JL. Neuronal morphology and the synaptic organisation of sympathetic ganglia. J Auton Nerv Syst. 2000 Jul 3;81(1-3):104-9.

79. Missler M, Südhof TC. Neurexins: three genes and 1001 products. Trends Genet. 1998 Jan;14(1):20-6.

80. de Wit J, Ghosh A. Specification of synaptic connectivity by cell surface interactions. Nat Rev Neurosci. 2016 Jan;17(1):22-35. doi: 10.1038/ nrn.2015.3. Epub 2015 Dec 10

81. Kramer ER, Knott L, Su F, Dessaud E, Krull CE, Helmbacher F, Klein R. Cooperation between GDNF/Ret and ephrinA/EphA4 signals for motor-axon pathway selection in the limb. Neuron. $2006 \mathrm{Apr}$ 6;50(1):35-47.

82. Bonanomi D, Chivatakarn O, Bai G, Abdesselem H, Lettieri K, Marquardt T, Pierchala BA, Pfaff SL. Ret is a multifunctional coreceptor that integrates diffusible- and contact-axon guidance signals. Cell. 2012 Feb 3;148(3):568-82. doi: 10.1016/j.cell.2012.01.024.

83. Carroll P, Gayet O, Feuillet C, Kallenbach S, de Bovis B, Dudley K, Alonso S. Juxtaposition of CNR protocadherins and reelin expression in the developing spinal cord. Mol Cell Neurosci. 2001 Apr;17(4):611-23.

84. Schalm SS, Ballif BA, Buchanan SM, Phillips GR, Maniatis T. Phosphorylation of protocadherin proteins by the receptor tyrosine kinase Ret. Proc Natl Acad Sci U S A. 2010 Aug 3;107(31):13894-9. doi: 10.1073/pnas.1007182107. Epub 2010 Jun 25.

85. Craig AM, Kang Y. Neurexin-neuroligin signaling in synapse development. Curr Opin Neurobiol. 2007 Feb;17(1):43-52. Epub 2007 Feb 1

86. Südhof TC. Synaptic Neurexin Complexes: A Molecular Code for the Logic of Neural Circuits. Cell. 2017 Nov 2;171(4):745-769. doi: 10.1016/j.cell.2017.10.024.

87. Takahashi H, Craig AM. Protein tyrosine phosphatases PTP $\delta, \operatorname{PTP} \sigma$ and LAR: presynaptic hubs for synapse organization. Trends Neurosci. 2013 Sep;36(9):522-34. doi: 10.1016/j.tins.2013.06.002. Epub 2013 Jul 5.

88. Um JW, Kim KH, Park BS, Choi Y, Kim D, Kim CY, Kim SJ, Kim M, Ko JS, Lee SG, Choii G, Nam J, Heo WD, Kim E, Lee JO, Ko J, Kim HM. Structural basis for LAR-RPTP/Slitrk complex-mediated synaptic adhesion. Nat Commun. 2014 Nov 14;5:5423. doi: 10.1038/ncomms6423.

89. Patzke H, Ernsberger U. Expression of neurexin Ialpha splice variants in sympathetic neurons: selective changes during differentiation and in response to neurotrophins. Mol Cell Neurosci. 2000 Jun;15(6):56172 . 